\title{
Herbaceous Encroachment from Mountain Birch Forests to Alpine Tundra Plant Communities Through Above- and Belowground Competition
}

\author{
Xinyuan Tan ${ }^{1}$, Hong S. He ${ }^{1,2, *}$, Shengwei Zong ${ }^{1, *}$, Miaomiao Wu ${ }^{1}$, Kai Liu ${ }^{1}$ and Dandan Zhao ${ }^{1}$ \\ 1 Key Laboratory of Geographical Processes and Ecological Security in Changbai Mountains, Ministry of \\ Education, School of Geographical Sciences, Northeast Normal University, Changchun 130024, China; \\ tanxy315@nenu.edu.cn (X.T.); wumm836@nenu.edu.cn (M.W.); liuk368@nenu.edu.cn (K.L.); \\ zhaodd982@nenu.edu.cn (D.Z.) \\ 2 School of Natural Resources, University of Missouri, Columbia, MO 65211, USA \\ * Correspondence: HeH@missouri.edu (H.S.H.); zongsw049@nenu.edu.cn (S.W.Z.); \\ Tel.: +1-573-882-7717 (H.S.H); +86-0431-8509-8953 (S.Z.)
}

Received: 1 February 2019; Accepted: 14 February 2019; Published: 16 February 2019

\begin{abstract}
Alpine plant communities are highly sensitive to global warming. One of the consequences of the warming is encroachment by herbaceous plants from forests at low elevations into alpine ecosystems. In the Changbai Mountains, narrowleaf small reed (Deyeuxia angustifolia (Kom.) Y. L. Chang) from mountain birch forests encroached upward into alpine tundra, gradually replacing native tundra shrubs such as Rhododendron (Rhododendron aureum Georgi). How encroaching plants affect native plant communities is not fully understood. In this study, we analyzed above- and belowground biomass of alpine plant communities at five encroachment levels to investigate how biomass allocation changed at species and community scales. Our research showed that native plants are forced to change their morphology to cope with competition, at both above- and belowground levels, from encroaching plants. We found that (1) R. aureum increased the shoot height and leaf area in order to compete with $D$. angustifolia; (2) above- and belowground biomass of $D$. angustifolia increased while above- and belowground biomass of $R$. aureum decreased with increasing levels of encroachment; and (3) D. angustifolia encroachment reduced the total biomass of alpine tundra. Encroachment by herbaceous plants has a long-term negative impact on the ability of tundra plants to sequester carbon in the alpine tundra of the Changbai Mountains.
\end{abstract}

Keywords: herbaceous encroachment; alpine tundra; competition; biomass allocation

\section{Introduction}

Alpine tundra is a fragile ecosystem that is very sensitive to environmental change [1]. The main environmental stress for tundra is low temperature. Alpine tundra is typically covered by snow for most of the year and the period for plant growth is limited to the short summer season. The poor soil, strong winds, and high ultraviolet radiation make establishment and growth difficult for most native alpine tundra plant species.

Globally, rapid changes in plant communities in alpine and arctic tundra have been observed over the past few decades. Some plant species from low elevations have expanded to high elevations in accordance with climate warming in alpine ecosystems [2]. Among these plant species $24.6 \%$ of the non-native species were herbaceous [2]. In the central Andes, the diversity and cover of non-native plants including some herbs have been found increasing in high elevations in past decades [3-5]. Moreover, some non-native herbs have expanded quickly through corridors, such as road and trail, in the montane area of Drakensberg Mountains [6]. In a trend that is predicted to accelerate, herbaceous 
species have expanded into the habitats of native species in the European Alps $[7,8]$. Such expansion would have significant influences on the structure and function of alpine plant communities.

Plants respond to different environmental conditions and levels of competition through changes of survival strategies [9]. In alpine tundra, encroaching herbaceous species elevated the competition for resources with tundra plants. Competition led to changes in survival strategies in all species (encroaching and tundra species) $[10,11]$. Encroaching plant species may have inhibitory effects on native plants, or even completely replace native plants in high-stress environments [12-14]. In order to compete for resources such as light and moisture, native plants can exhibit plasticity in morphological traits such as shoot height and leaf width [15] or adjust the carbon allocation to aboveground and belowground parts [15-18]. It has been suggested that plants may respond to environmental stress by increasing the distribution of the belowground parts to obtain more nutrients from soil [19]. Studies at a high arctic oasis on Ellesmere Island concluded that herbaceous species were more sensitive to nutrient availability than shrub species $[20,21]$. Encroaching plants in tundra may also make adjustments in survival strategies to compete for limited resources [22,23].

The alpine tundra of the Changbai Mountains is one of two tundra areas in China. This vegetative community has experienced rapid changes since the late 1990s [24]. Narrowleaf small reed (Deyeuxia angustifolia (Kom.) Y. L. Chang), a perennial herb that once existed in the understory of mountain birch forests at lower elevations, has now moved into the tundra plant communities. It is a small reed with narrow leaves, fast growth, clonal and sexual reproductive modes, high seed production, and anemochory. D. angustifolia has a short juvenile period and is generally distributed in moist habitats [25]. In the 1970s, D. angustifolia was absent in the tundra plant communities [26], while $D$. angustifolia was found in $R$. aureum communities with less than $10 \%$ at low elevation areas from the survey results of the 1990s [27]. Thus, we refer to D. angustifolia as an encroaching species [28]. $D$. angustifolia is now widespread with a patchy distribution in the alpine tundra. The expansion of $D$. angustifolia has altered the landscape and tundra plant community, greatly affecting the abundance of tundra plants such as R. aureum.

In this study, we intend to answer the following questions: What strategies do D. angustifolia use to gain a competitive advantage as an encroaching species? What strategies do tundra plants use in response to competition from $D$. angustifolia? How do changes in the composition of the tundra plant community affect carbon stock? We will answer these questions by testing the following predictions: (1) encroaching herbaceous plants gain advantages through both aboveground competition and belowground competition; (2) native tundra plants are forced to change their morphology to cope with competition from the encroaching species; and (3) herbaceous encroachment leads to an overall decrease in vegetation carbon stock of alpine tundra.

\section{Materials and Methods}

\subsection{Study Area}

The Changbai Mountain Nature Reserve is located in Jilin province, Northeast China (Figure 1). It has five unique vegetation zones arranged vertically from low altitude to high altitude: a deciduous broad-leaved forest zone below $500 \mathrm{~m}$; a mixed deciduous broad-leaved/conifer forest zone between 500 and $1100 \mathrm{~m}$; a coniferous forest zone between 1100 and $1700 \mathrm{~m}$; a mountain birch forest zone between 1700 and $2000 \mathrm{~m}$; and a tundra zone above $2000 \mathrm{~m}$ [29]. The alpine tundra of the Changbai Mountains has a short growing season between June and September every year. The tundra is covered by snow outside the growing season. The temperature during the growing season ranges from 7.3 to $10.6^{\circ} \mathrm{C}$ (mean temperature is $8.9^{\circ} \mathrm{C}$ ). The mean growing-season temperature has increased by 0.239 ${ }^{\circ} \mathrm{C}$ per decade over the past several decades [30]. The annual precipitation ranges from 558.7 to 1553.7 $\mathrm{mm}$ (mean precipitation is $1056.27 \mathrm{~mm}$ ) [31]. As a result of the harsh environment, the vegetation structure is relatively simple: typical tundra plants are dwarf shrubs. Our study area is located on the western aspect of the Changbai Mountain $\left(41^{\circ} 59^{\prime} \mathrm{N}, 128^{\circ} 01^{\prime} \mathrm{E} ; 2200 \mathrm{~m}\right)$. The dominant native 
plant species in the tundra include evergreen dwarf shrubs such as Rhododendron (Rhododendron aureum Georgi), blueberry (Vaccinium uliginosum Linn.), mountain avens (Dryas octopetala L.), azaleas (Rhododendron confertissimum Nakai), and Phyllodoce (Phyllodoce caerulea (L.) Bab.). Some perennial herbaceous species are widely distributed, such as Sanguisorba stipulata (Sanguisorba sitchensis C. A. Mey.), Sanguisorba parviflora (Sanguisorba tenuifolia Fisch. var. alba Trautv. et Mey.), hawkweed (Hieracium coreanum Nakai), ligularia fischeri (Ligularia jamesii (Hemsl.) Kom.), and monkshood (Aconitum tschangbaischanense S. H. Li \& Y. H. Huan). During the past few decades, D. angustifolia from low elevations has been encroaching into the alpine tundra ecosystem, mainly threatening $R$. aureum communities [28]. We compared the data from Qian (1979) and Qian (1992) with ours to see whether the abundance of D. angustifolia increased gradually over time. Qian (1979) showed that the alpine tundra in Changbai Mountains was dominated by $R$. aureum and that D. angustifolia was absent in the tundra plant communities [26]. D. angustifolia was first reported by Qian in 1992 [27]. He found that $D$. angustifolia was found in R. aureum communities with less than $10 \%$ at low elevation areas. However, according to our recent survey in 2010, D. angustifolia became dominant at the same areas where $R$. aureum was found standing dead [30].

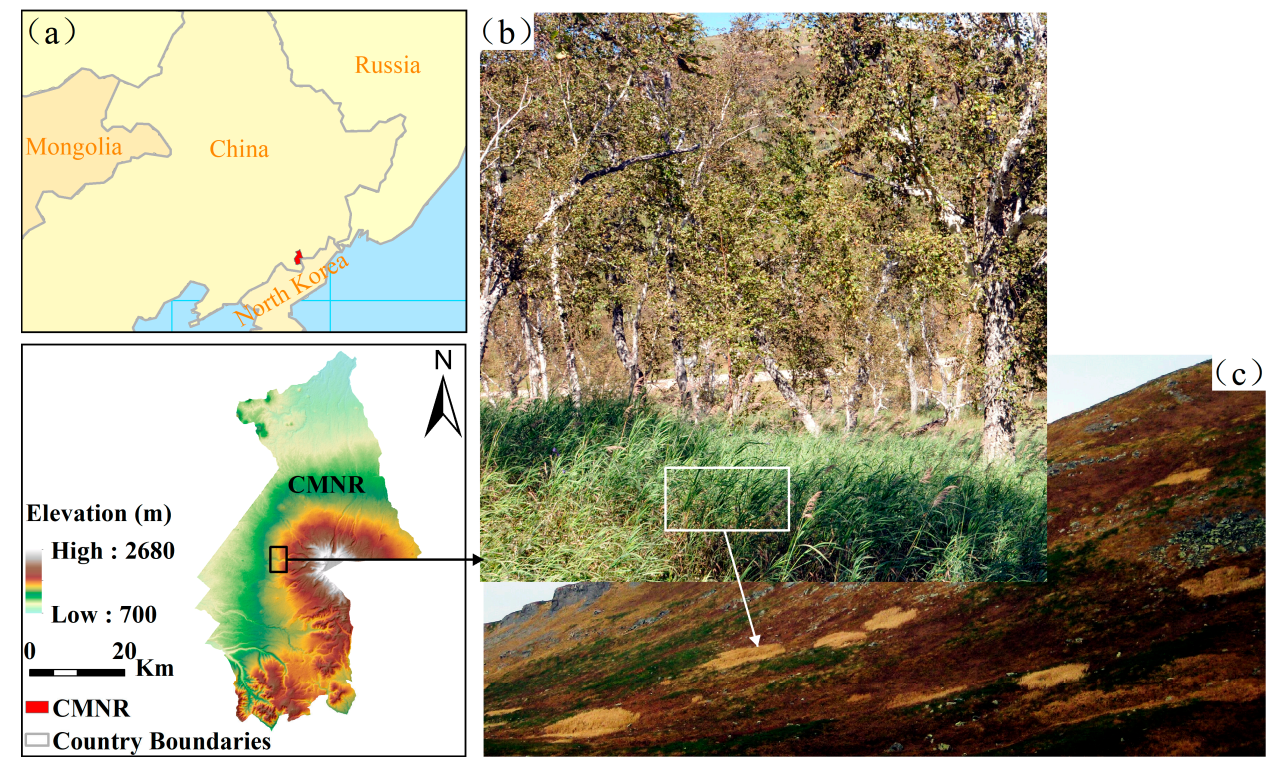

Figure 1. Location of the Changbai Mountain Nature Reserve (CMNR) in Northeastern China (a), mountain birch and Deyeuxia angustifolia (inset) communities in mountain birch forests located between 1700 and $2000 \mathrm{~m} \mathrm{(b)}$, and alpine tundra (above $2000 \mathrm{~m}$ ) with patches of encroaching D. angustifolia located on the western aspect of the Changbai Mountains (c).

\subsection{Sampling Design}

According to our previous study, there was a gradual expansion process of D. angustifolia after it established in the R. aureum communities. From remote sensing which revealed long-term dynamics of D. angustifolia communities, Zong et al. (2013) analyzed changes in the NDVI of D. angustifolia patches from 1983 to 2008 and found that NDVI decreased gradually [30]. R. aureum showed greenness, while $D$. angustifolia showed yellowness at the end of the growing season. We concluded that D. angustifolia gradually replaced $R$. aureum during the past three decades. In addition, Zong et al. (2014) transplanted $D$. angustifolia patches $(30 \times 30 \mathrm{~cm})$ into $R$. aureum patches to observe the expansion process of $D$. angustifolia and found that $D$. angustifolia expanded outside of the patches at rate of 9 shoots per year, indicating a low expansion rate [28]. Furthermore, Wu et al. (2018) processed time-series Landsat satellite images (from 1988 to 2017) of the sampling areas [32]. The resolution of the image was $30 \times 30 \mathrm{~m}$. Randomly taking single pixels from images, including those of our sampling area, Wu et al. (2018) showed that NDVI gradually decreased over time at the sampling areas, which indicated that 
the encroachment levels of D. angustifolia gradually increased (Figure 2). Thus, we believe the method of "space-for-time substitution" can be used [33] to investigate the biomass reallocation process at the community level.

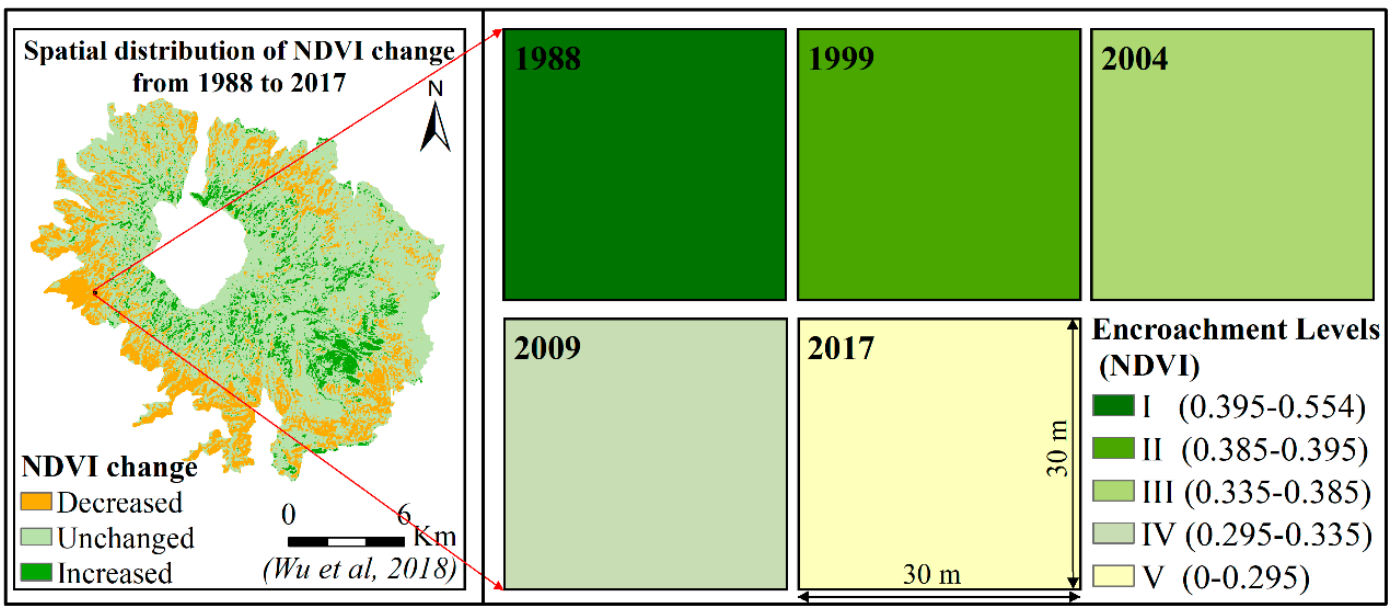

Figure 2. Location of our sampling area in alpine tundra (above $2000 \mathrm{~m}$ ) of Changbai Mountains (on the left of figure [32]) and NDVI of the time-series satellite images of communities with different $D$. angustifolia encroachment levels in the sampling area (on the right of figure).

At each of our plots, we classified the D. angustifolia encroachment into one of five levels based on the percentage of cover of D. angustifolia and R. aureum: no encroachment (I) (cover of D. angustifolia $0 \%$; R. aureum 100\%), low encroachment (II) ( $0 \%<$ cover of D. angustifolia $\leq 30 \% ; 70 \% \leq$ cover of $R$. aureum $<100 \%)$, medium encroachment (III) (30\% < cover of D. angustifolia $\leq 70 \% ; 30 \% \leq$ cover of R. aureum $<70 \%)$, high encroachment (IV) $(70 \%<$ cover of D. angustifolia $<100 \% ; 0 \%<$ cover of $R$. aureum $<30 \%$ ), and complete encroachment (V) (cover of D. angustifolia $100 \%$; R. aureum 0\%) (Figure 3). Communities with no encroachment or complete encroachment were monoculture communities that included only R. aureum or D. angustifolia. Mixed communities at a low encroachment level, a medium encroachment level, and a high encroachment level with unitary structures included a mixture of the two. We did not consider other plants in these communities because of their low abundances.
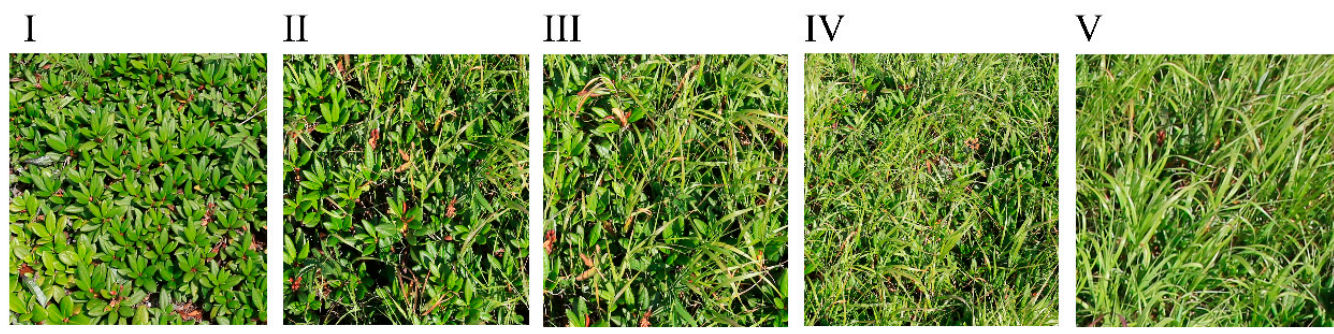

Figure 3. Pictures of Rhododendron aureum communities under five Deyeuxia angustifolia encroachment levels: no encroachment (I) had a cover of $D$. angustifolia of $0 \%$, low encroachment (II) had a cover of $D$. angustifolia between 0 and 30\%, medium encroachment (III) had a cover of D. angustifolia between 30 and $70 \%$, high encroachment (IV) had a cover of D. angustifolia between 70 and $100 \%$, and complete encroachment $(\mathbf{V})$ had a cover of D. angustifolia of $100 \%$.

Elevation and topography gradients may create variable micro-environment (e.g., temperature and soil moisture), leading to changes in plant morphology [34,35]. To avoid this confounding factor, we used the stratified-random sample design. Stratified sampling was carried out in 6 random plots (equal size) with similar topographical conditions (a slope between 21 and $28^{\circ}$ and soil moisture between 0.05 and $0.3 \mathrm{~m}^{3} / \mathrm{m}^{3}$ ) at an elevation of $2200 \mathrm{~m}$, where plant communities with the five levels of D. angustifolia encroachment could be found. In each plot $(10 \times 10 \mathrm{~m})$, we sampled the above- and 
belowground biomass in three $10 \times 10 \mathrm{~cm}$ quadrats randomly for each encroachment level (total = 15 quadrats per plot). Meanwhile, in each quadrat, we randomly selected three shoots that could reflect the average height of the species in the communities. We measured the height of R. aureum and D. angustifolia from three replicate plants, and the average height of the three plants was taken as the height of the two plant species in the communities. Leaf area was measured from the plants that were selected to represent the average status of growth using a leaf area meter (Yaxin-1241, Beijing Yaxinliyi Science and Technology Inc., Beijing, China). The aboveground vegetative parts in every quadrat was clipped at the soil surface and sorted into leaves and stems for R. aureum and D. angustifolia. To efficiently extract root form soil, we removed large stones first. Roots were separated from most of the soil through sieves of different mesh sizes as much as possible. We then placed roots into fine-mesh bags and washed the bags to remove soil. After the washing treatment, we extracted roots with different diameter using forceps [36]. The roots of R. aureum and D. angustifolia were identified after the above process. The soil sampling depth depended on how deep the roots of plants can reach. The root depth of $R$. aureum in monoculture community was about $16 \mathrm{~cm}$, while the root depth of $D$. angustifolia in monoculture community was about $22 \mathrm{~cm}$. The roots of the two focal species could be distinguished by color and texture: roots of $D$. angustifolia were white and smooth, while the roots of R. aureum were brownish or reddish with a woody texture [29]. We sorted roots to different fractions according to the root diameter: coarse roots (diameter $>3 \mathrm{~mm})$, medium roots $(1 \mathrm{~mm}<$ diameter $\leq 3$ $\mathrm{mm}$ ), and fine roots (diameter $\leq 1 \mathrm{~mm}$ ) for $R$. aureum, and medium roots $(1 \mathrm{~mm}<\operatorname{diameter} \leq 3 \mathrm{~mm})$ and fine roots (diameter $\leq 1 \mathrm{~mm}$ ) for D. angustifolia. All samples including above- and belowground parts were oven-dried at the temperature of $65^{\circ} \mathrm{C}$ until the weight of dry mass no longer changed. We applied the mass density $\left(\mathrm{kg} / \mathrm{m}^{2}\right)$ as a measure of all biomass parts.

\subsection{Data Analysis}

We calculated the aboveground biomass (e.g., stems and leaves), belowground biomass (roots of various diameters), and total biomass of R. aureum, D. angustifolia, and the entire plant community. In addition to weighing the absolute biomass, we also calculated root/shoot ratio and biomass fractions including the leaf biomass ratio, stem biomass ratio, fine root biomass ratio, medium root biomass ratio, and coarse root biomass ratio (Table 1 ) [37,38].

Table 1. Biomass variables used in analyses, together with formula and the descriptions.

\begin{tabular}{|c|c|c|}
\hline Variables & Formula & Descriptions \\
\hline Leaf biomass allocation (LBA) & Leaf biomass / total biomass $\times 100 \%$ & $\begin{array}{l}\text { The percentage of leaf biomass of the } \\
\text { total biomass of the plant }\end{array}$ \\
\hline Stem biomass allocation (SBA) & Stem biomass / total biomass $\times 100 \%$ & $\begin{array}{l}\text { The percentage of stem biomass of the } \\
\text { total biomass of the plant }\end{array}$ \\
\hline $\begin{array}{l}\text { Fine root biomass allocation } \\
\text { (FRBA) }\end{array}$ & Fine root biomass / total biomass $\times 100 \%$ & $\begin{array}{l}\text { The percentage of fine root biomass of } \\
\text { the total biomass of the plant }\end{array}$ \\
\hline $\begin{array}{l}\text { Medium root biomass allocation } \\
\text { (MRBA) }\end{array}$ & Medium root biomass/total biomass $\times 100 \%$ & $\begin{array}{l}\text { The percentage of medium root biomass } \\
\text { of the total biomass of the plant }\end{array}$ \\
\hline $\begin{array}{l}\text { Coarse root biomass allocation } \\
\text { (CRBA) }\end{array}$ & Coarse root biomass / total biomass $\times 100 \%$ & $\begin{array}{c}\text { The percentage of coarse root biomass } \\
\text { of the total biomass of the plant }\end{array}$ \\
\hline Root/shoot ratio (R/S) & Belowground biomass / aboveground biomass & $\begin{array}{c}\text { The relationship between aboveground } \\
\text { and belowground biomass }\end{array}$ \\
\hline
\end{tabular}

In order to determine whether the data met assumptions of normality and homoscedasticity, all data were tested using Shapiro-Wilk and Levene tests in SPSS before using ANOVA to examine the difference in communities' biomass and biomass allocation among different encroachment levels. Results showed that most of the variables passed the test $(p>0.05)$. If data of any variable did not pass the test, we transformed the data to make it suitable for ANOVA analysis. We considered encroachment level and plot as two main factors in all statistical analyses by two-way ANOVA for analyzing above and belowground biomass. Subsequent Fisher's least significant difference (LSD) tests were used to examine the difference in communities' biomass and biomass allocation among different encroachment 
levels. All statistical analyses were conducted using SPSS 22.0 (SPSS Inc., Chicago, IL, USA). For each of the statistical analyses, the levels of significance were $p<0.05$.

\section{Results}

Results show that interactions between plots and encroachment levels were not significant $(p>0.05)$ (Tables S1 and S2). The main effects of plot and encroachment level were calculated (Tables 2 and 3). Table 2 shows the test results of the respective main effects of the plot and encroachment level of $R$. aureum biomass, height, and leaf area. Table 3 shows the test results of the respective main effect of the plot and encroachment level of D. angustifolia biomass, height, and leaf area. Results show that plot effects on most dependent variables, except for the leaf area (RAR) of R. aureum, were not significant. This might be because of the growth of plants at different habitats. Encroachment level effects on most dependent variables, except for medium root biomass (RMRB) and coarse root biomass (RCRB) of R. aureum, were significant, indicating that the allocation of plant biomass was affected by encroachment levels.

Table 2. The F tests the effect of the plot and of the encroachment level of R. aureum biomass, height, and leaf area.

\begin{tabular}{|c|c|c|c|c|c|c|c|}
\hline \multirow{2}{*}{\multicolumn{2}{|c|}{ Dependent Variable }} & \multicolumn{3}{|c|}{ Plot } & \multicolumn{3}{|c|}{ Encroachment Level } \\
\hline & & \multirow{2}{*}{$\begin{array}{c}\mathbf{d f} \\
5 \\
63\end{array}$} & \multirow{2}{*}{\begin{tabular}{c|}
$\mathbf{F}$ \\
0.095
\end{tabular}} & \multirow{2}{*}{$\begin{array}{c}\text { Sig. } \\
0.993\end{array}$} & \multirow{2}{*}{$\begin{array}{c}\mathrm{df} \\
3 \\
63\end{array}$} & \multirow{2}{*}{$\begin{array}{c}\text { F } \\
52.642\end{array}$} & \multirow{2}{*}{$\begin{array}{r}\text { Sig. } \\
0.000\end{array}$} \\
\hline RLB & $\begin{array}{c}\text { Contrast } \\
\text { Error }\end{array}$ & & & & & & \\
\hline RSB & $\begin{array}{c}\text { Contrast } \\
\text { Error }\end{array}$ & $\begin{array}{c}5 \\
63\end{array}$ & 0.219 & 0.953 & $\begin{array}{c}3 \\
63\end{array}$ & 44.168 & 0.000 \\
\hline RFRB & $\begin{array}{c}\text { Contrast } \\
\text { Error }\end{array}$ & $\begin{array}{c}5 \\
63\end{array}$ & 2.418 & 0.050 & $\begin{array}{c}3 \\
63\end{array}$ & 29.148 & 0.000 \\
\hline RMRB & $\begin{array}{c}\text { Contrast } \\
\text { Error }\end{array}$ & $\begin{array}{c}5 \\
63\end{array}$ & 0.408 & 0.841 & $\begin{array}{c}3 \\
63\end{array}$ & 2.552 & 0.076 \\
\hline RCRB & $\begin{array}{c}\text { Contrast } \\
\text { Error }\end{array}$ & $\begin{array}{c}5 \\
63\end{array}$ & 0.311 & 0.895 & $\begin{array}{c}3 \\
63\end{array}$ & 3.003 & 0.058 \\
\hline $\mathrm{RH}$ & $\begin{array}{c}\text { Contrast } \\
\text { Error }\end{array}$ & $\begin{array}{c}5 \\
63\end{array}$ & 0.408 & 0.841 & $\begin{array}{c}3 \\
63\end{array}$ & 199.027 & 0.000 \\
\hline RAR & $\begin{array}{c}\text { Contrast } \\
\text { Error }\end{array}$ & $\begin{array}{c}5 \\
63\end{array}$ & 2.698 & 0.028 & $\begin{array}{c}3 \\
63\end{array}$ & 71.157 & 0.000 \\
\hline
\end{tabular}

This test is based on the linearly independent pairwise comparisons among the estimated marginal means.

Table 3. The F tests the effect of the plot and of the encroachment level of D. angustifolia biomass, height, and leaf area

\begin{tabular}{|c|c|c|c|c|c|c|c|}
\hline \multirow{2}{*}{\multicolumn{2}{|c|}{ Dependent Variable }} & \multicolumn{3}{|c|}{ Plot } & \multicolumn{3}{|c|}{ Encroachment Level } \\
\hline & & \multirow{2}{*}{$\begin{array}{c}\mathbf{d f} \\
5 \\
63\end{array}$} & \multirow{2}{*}{$\begin{array}{c}\mathbf{F} \\
0.789\end{array}$} & \multirow{2}{*}{$\begin{array}{c}\text { Sig. } \\
0.561\end{array}$} & \multirow{2}{*}{$\begin{array}{c}\mathbf{d f} \\
3 \\
63\end{array}$} & \multirow{2}{*}{$\begin{array}{c}\mathbf{F} \\
120.950\end{array}$} & \multirow{2}{*}{$\frac{\text { Sig. }}{0.000}$} \\
\hline DLB & $\begin{array}{c}\text { Contrast } \\
\text { Error }\end{array}$ & & & & & & \\
\hline DSB & $\begin{array}{c}\text { Contrast } \\
\text { Error }\end{array}$ & $\begin{array}{c}5 \\
63\end{array}$ & 0.970 & 0.443 & $\begin{array}{c}3 \\
63\end{array}$ & 97.236 & 0.000 \\
\hline DFRB & $\begin{array}{c}\text { Contrast } \\
\text { Error }\end{array}$ & $\begin{array}{c}5 \\
63\end{array}$ & 0.480 & 0.790 & $\begin{array}{c}3 \\
63\end{array}$ & 42.122 & 0.000 \\
\hline DMRB & $\begin{array}{c}\text { Contrast } \\
\text { Error }\end{array}$ & $\begin{array}{c}5 \\
63\end{array}$ & 0.886 & 0.496 & $\begin{array}{c}3 \\
63\end{array}$ & 89.355 & 0.000 \\
\hline DAR & $\begin{array}{c}\text { Contrast } \\
\text { Error }\end{array}$ & $\begin{array}{c}5 \\
63\end{array}$ & 1.276 & 0.286 & $\begin{array}{c}3 \\
63\end{array}$ & 40.698 & 0.000 \\
\hline $\mathrm{DH}$ & $\begin{array}{c}\text { Contrast } \\
\text { Error }\end{array}$ & $\begin{array}{c}5 \\
63\end{array}$ & 0.407 & 0.842 & $\begin{array}{c}3 \\
63\end{array}$ & 39.976 & 0.000 \\
\hline
\end{tabular}

This test is based on the linearly independent pairwise comparisons among the estimated marginal means. 


\subsection{Changes in Plant Morphology}

Both $R$. aureum and D. angustifolia responded morphologically to inter-specific competition based on the level of encroachment (Figure 4). With increasing levels of encroachment, the height of R. aureum increased significantly ( $\mathrm{F}=199.027, p<0.05)$ (Figure 3a), especially at the medium (III) and high (IV) encroachment levels. The height of $R$. aureum increased by $53 \%$ at the medium encroachment level and by $108 \%$ at the high encroachment level, compared with the low encroachment level. Similarly, the height of D. angustifolia also increased significantly $(\mathrm{F}=39.976, p<0.05)$, especially at the high (IV) encroachment level. It increased by 50\% from the low encroachment levels, but the extent of the increase was not as high as R. aureum.
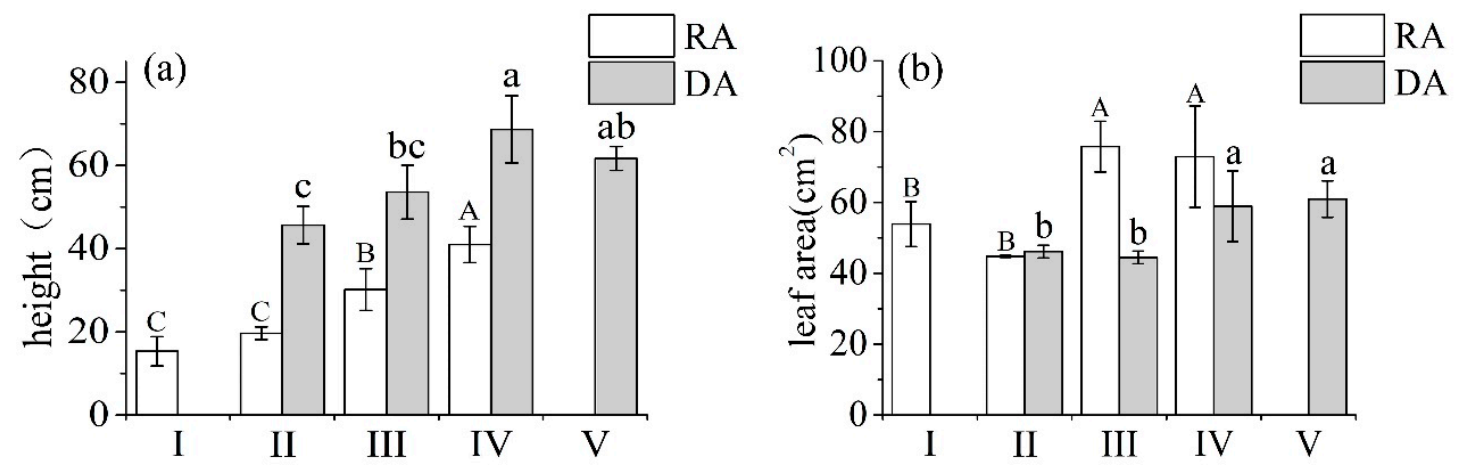

Figure 4. Plant height (a) and average leaf area (b) of Deyeuxia angustifolia (DA) and Rhododendron aureum (RA), in plant communities under five encroachment levels. Different capital and lower-case letters indicate significant differences among RA and DA, respectively, at the five encroachment levels $(p<0.05)$ according to two-way ANOVA with Fisher's least significant difference (LSD) test.

Increasing $D$. angustifolia encroachment resulted in the increase of average leaf area of both $R$. aureum $(\mathrm{F}=71.157, p<0.05)$ and D. angustifolia $(\mathrm{F}=40.698, p<0.05)$ (Figure 3b). In particular, compared with low encroachment levels (II), the average leaf area of $R$. aureum increased significantly by $79 \%$ at medium (III) and high (IV) encroachment levels. Average leaf area of D. angustifolia increased significantly by $35 \%$ at high (IV) encroachment levels.

\subsection{Changes in Biomass and Allocation}

R. aureum's biomass differed significantly among the five encroachment levels (Figure 5a). With increasing levels of encroachment, the total (above- and belowground) biomass of $R$. aureum gradually reduced $(\mathrm{F}=8.017, p<0.05)$. The largest reduction occurred between the medium (III) and high (IV) encroachment levels. Both aboveground $(\mathrm{F}=8.152, p<0.05)$ and belowground $(\mathrm{F}=10.759, p<0.05)$ biomass allocations by R. aureum changed significantly (Table 4). From no encroachment (I) to medium encroachment (III), aboveground biomass allocations to leaves and stems increased, and belowground biomass allocations to roots decreased, but the changes were not significant $(p>0.05)$. However, at high encroachment levels (IV), R. aureum significantly reduced aboveground biomass allocations $(p<0.05)$ while significantly increasingly belowground biomass allocations $(p<0.05)$. Allocations to different parts of R. aureum changed differently across encroachment levels. From the no encroachment level (I) to the medium encroachment level (III), leaf biomass $\left(\mathrm{kg} / \mathrm{m}^{2}\right)$ did not change significantly; however, leaf biomass was significantly reduced at the high encroachment level (IV) $(\mathrm{F}=52.642, p<0.05)$. Leaf biomass allocation had no significant changes $(p>0.05)$. Stem biomass $\left(\mathrm{kg} / \mathrm{m}^{2}\right)(\mathrm{F}=44.168$, $p<0.05)$ and stem biomass allocation $(\mathrm{F}=11.230, p<0.05)$ gradually reduced with increasing levels of encroachment. Fine root biomass $\left(\mathrm{kg} / \mathrm{m}^{2}\right)(\mathrm{F}=29.148, p<0.05)$ and fine root biomass allocation $(\mathrm{F}=4.934, p<0.05)$ also exhibited a gradual reduction as levels of encroachment increased. Medium root biomass and allocation did not change $(p>0.05)$. Coarse root biomass did not change $(p>0.05)$, but coarse root biomass allocation increased significantly $(\mathrm{F}=12.348, p<0.05)$. It was notable that, 
at each encroachment level, belowground biomass was higher than aboveground biomass and the root/shoot ratio increased as encroachment level increased $(\mathrm{F}=5.727, p<0.05)$ (Figure 6).
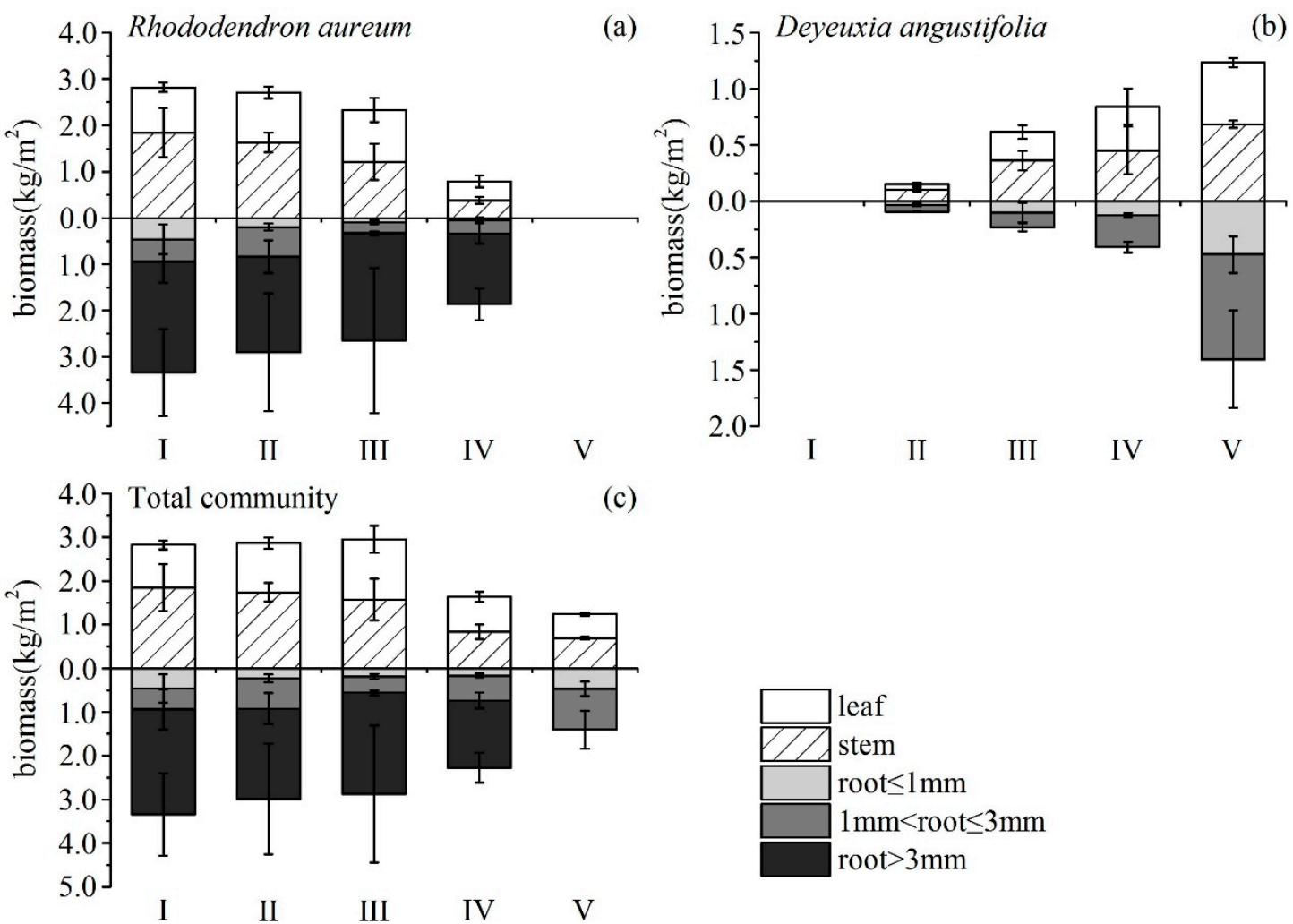

Figure 5. Biomass of different parts of Rhododendron aureum (a), Deyeuxia angustifolia (b), and the whole community (c), under five encroachment levels.

Table 4. Biomass allocation to different parts of R. aureum (RA) and D. angustifolia (DA) in plant communities under five encroachment levels.

\begin{tabular}{ccccccc}
\hline Plant Type & $\begin{array}{c}\text { Level of } \\
\text { Encroachment }\end{array}$ & LBA & SBA & FRBA & MRBA & CRBA \\
\hline \multirow{4}{*}{ RA } & I & $17.11 \pm 0.06 \mathrm{a}$ & $30.46 \pm 0.03 \mathrm{a}$ & $7.30 \pm 0.04 \mathrm{a}$ & $6.78 \pm 0.05 \mathrm{a}$ & $38.35 \pm 0.03 \mathrm{ab}$ \\
& II & $19.52 \pm 0.02 \mathrm{a}$ & $29.64 \pm 0.04 \mathrm{a}$ & $3.49 \pm 0.01 \mathrm{ab}$ & $12.17 \pm 0.07 \mathrm{a}$ & $35.18 \pm 0.14 \mathrm{~b}$ \\
& III & $27.70 \pm 0.15 \mathrm{a}$ & $29.19 \pm 0.14 \mathrm{a}$ & $2.19 \pm 0.01 \mathrm{~b}$ & $5.84 \pm 0.03 \mathrm{a}$ & $52.01 \pm 0.20 \mathrm{ab}$ \\
& IV & $14.98 \pm 0.02 \mathrm{a}$ & $14.80 \pm 0.04 \mathrm{~b}$ & $1.48 \pm 0.02 \mathrm{~b}$ & $10.39 \pm 0.08 \mathrm{a}$ & $58.35 \pm 0.12 \mathrm{a}$ \\
& V & & & & & \\
\hline \multirow{2}{*}{ DA } & I & & & & & \\
& II & $19.64 \pm 0.06 \mathrm{~b}$ & $43.12 \pm 0.06 \mathrm{a}$ & $13.38 \pm 0.05 \mathrm{ab}$ & $23.87 \pm 0.02 \mathrm{~b}$ & \\
& III & $30.21 \pm 0.05 \mathrm{a}$ & $42.96 \pm 0.07 \mathrm{a}$ & $6.00 \pm 0.01 \mathrm{~b}$ & $15.48 \pm 0.03 \mathrm{~b}$ & \\
\hline & IV & $30.79 \pm 0.03 \mathrm{a}$ & $35.32 \pm 0.06 \mathrm{ab}$ & $10.64 \pm 0.04 \mathrm{ab}$ & $23.25 \pm 0.04 \mathrm{~b}$ & \\
\hline
\end{tabular}

Different lower-case letters indicate a significant difference in results of RA and DA within five encroachment levels $(p<0.05)$ according to two-way ANOVA with Fisher's least significant difference (LSD) test.

D. angustifolia's biomass differed significantly across the five encroachment levels, (Figure 5b, Table 4). From low encroachment (II) to complete encroachment (V), aboveground biomass allocation reduced significantly, while belowground biomass allocation increased significantly $(\mathrm{F}=50.565$, $p<0.05 ; \mathrm{F}=21.424, p<0.05$, respectively). Leaf biomass $(\mathrm{F}=120.950, p<0.05)$ and leaf biomass allocation $(\mathrm{F}=37.373, p<0.05)$ increased significantly as encroachment level increased. Stem biomass increased significantly $(\mathrm{F}=97.236, p<0.05)$. Stem biomass allocation had no significant changes from low encroachment (II) to high encroachment (IV), but was significantly reduced at the complete 
encroachment level $(\mathrm{V})(\mathrm{F}=36.419, p<0.05)$. Fine roots biomass, medium roots biomass, and their respective allocations showed no significant changes $(p>0.05)$ from low (II) to high (IV) encroachment levels. However, fine roots biomass and allocation $(\mathrm{F}=42.122, p<0.05, \mathrm{~F}=4.260, p<0.05$, respectively), as well as medium roots biomass and allocation $(\mathrm{F}=89.355, p<0.05, \mathrm{~F}=21.600, p<0.05$ respectively), increased significantly at the complete encroachment level (V). It was notable that, until complete encroachment, aboveground biomass was higher than belowground biomass, and the root/shoot ratio increased as encroachment level increased $(\mathrm{F}=11.237, p<0.05)$ (Figure 6).

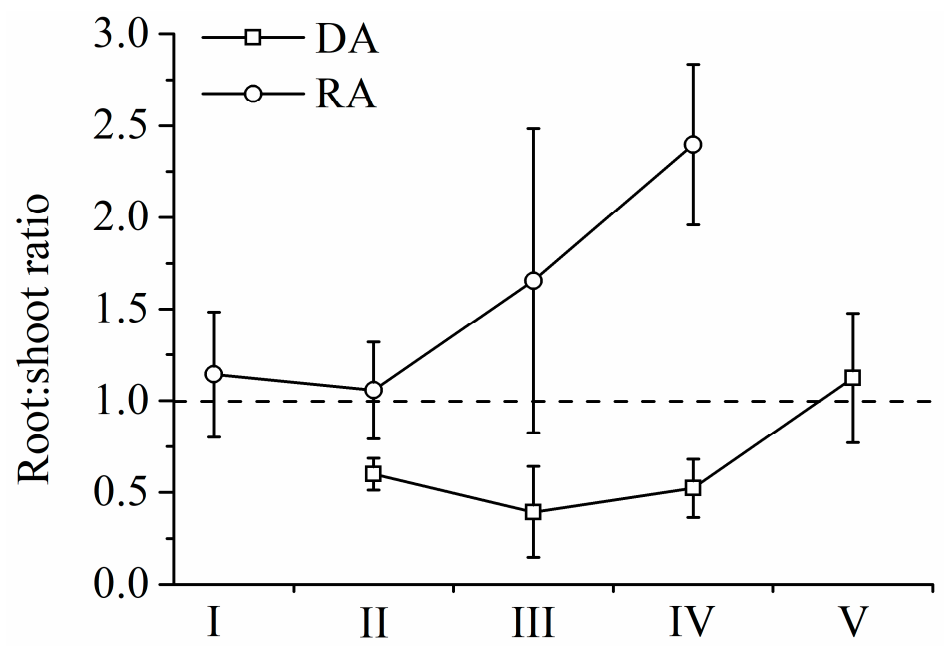

Figure 6. Root/shoot ratio of R. aureum and D. angustifolia under five encroachment levels.

Aboveground and belowground biomass of the community exhibited a gradual reduction as the encroachment level increased $(\mathrm{F}=8.311, p<0.05 ; \mathrm{F}=1.008, p>0.05$, respectively). The total biomass of the community showed a similar pattern $(\mathrm{F}=3.190, p<0.1)$ (Figure $5 \mathrm{c})$, probably as a result of the significant decline in leaf $(\mathrm{F}=10.747, p<0.05)$ and stem $(\mathrm{F}=7.325, p<0.05)$ biomass throughout the community, especially at the high encroachment level. At the community level, fine root biomass and medium root biomass exhibited no significant changes as a result of encroachment $(p>0.05)$. It was notable that the patterns of allocation did not always show consistent differences with level of encroachment or no differences at all (Table 4). This may reflect that biomass was allocated to different plant tissues with different competition mechanisms.

\section{Discussion}

The alpine tundra ecosystem is under stressful environmental conditions in which plants compete for limited resources [39]. Competition intensifies as exotic species encroach under changing climate conditions $[7,40]$. Our results showed that, as encroachment levels increased in the alpine tundra of the Changbai Mountains, the biomass of D. angustifolia gradually increased while the biomass of R. aureum declined. This competitive relationship favored the expansion of $D$. angustifolia at the expense of native plants. Some studies have shown that plant interactions shift from competition to facilitation as levels of environmental stress increase in alpine ecosystems [41]. The main mechanism underlying facilitation is the amelioration of extreme thermal conditions and protection from the strong desiccating winds by neighboring plants [8]. Since growth is not temperature-dependent in either focal species [29], neither plant species may benefit from this sort of thermal facilitation. Instead, we found that both plant species prefer low-lying areas with high soil moisture, indicating similar habitat requirements [25,42]. Numerous studies have found that encroaching plant species generally become established within a specific site or plant community, which suggested foreseeable competition with native plants after this initial encroachment stage [8,43-45]. Therefore, we emphasize that competition plays as an important role in controlling community dynamics in the context of alpine plant movements. 
Since micro-topography played a role in mediating alpine vegetation [34,35], the patterns of biomass at the different levels of encroachment may be affected by different microsites at local scales. However, we did not pursue this line of research because the graduate encroachment process was more predominant than microsite effects in alpine tundra of the Changbai Mountains as verified by both time-series satellite images and field observations $[26,27,32]$. We expect that the levels of encroachment as a result microsite differences would lead to the similar results to those of graduate encroachment in terms of above and belowground biomass patterns.

\subsection{Aboveground Competition}

Our findings support the first hypothesis that native alpine tundra plants are forced to change their morphology in response to competition from an encroaching species from lower altitudes of the Changbai Mountains. Small size and slow growth rate is a survival strategy for alpine plants that experience strong winds, low temperatures, and low resources [42]. The native R. aureum, a dwarf alpine shrub, increased its height and average leaf area in response to competition from D. angustifolia. Previous studies have shown that plants may change morphology (e.g., increasing height for light) because of competition $[13,46]$. At our site, D. angustifolia grows into dense populations, creating a shaded environment, when it becomes dominant in the community. In such a community, R. aureum needs to increase the height and leaf area to ensure adequate levels of photosynthesis. However, increases in height may have negative impacts on plant growth [47]; tall shrubs may not be fully covered by snow, resulting in exposure to freezing damage. Damage from freezing temperatures may be particularly severe with reduced snow cover under warming climate conditions [48]. R. aureum is known to have a narrow thermal tolerance, especially for low temperatures [42]. By contrast, $D$. angustifolia keeps all living tissue underground during the winter, and is free of freezing damage. Therefore, R. aureum may suffer disproportionately from the consequences of increased plant height [49, 50], giving D. angustifolia a competitive edge over R. aureum.

\subsection{Belowground Competition}

Native alpine plants allocated about $70 \%$ of biomass to belowground tissues [49]. Hence, we conclude that belowground competition was important for the expansion of D. angustifolia compared with aboveground competition $[29,51,52]$. The root/shoot ratio of $R$. aureum increased as encroachment level increased, indicating that competition gradually shifted from aboveground to belowground [53]. $D$. angustifolia encroachment led to a significant reduction of fine root biomass of $R$. aureum, which may restrict the growth of $R$. aureum. Fine roots are an important part of belowground biomass, which determines the nutrient and water absorption of plants from the soil [54]. By contrast, fine root biomass of $D$. angustifolia increased significantly at higher levels of encroachment, which allowed D. angustifolia to gain a competitive advantage.

In alpine ecosystems where resources were limited, herbaceous species generally have a stronger ability to absorb nitrogen and a higher resource utilization efficiency (e.g., carbon assimilation per unit of resource) than shrubs [55]. In this study area, other analyses have indicated that the nitrogen fixation and absorption ability of $D$. angustifolia was stronger than that of R. aureum [56]. Thus, species-specific differences in the ability to absorb nitrogen may have played an important role in plant competition in this setting [57,58]. As a fast-growing plant species, D. angustifolia requires a large amount of nitrogen to complete its life cycle [29]. Other studies have shown that the organic compounds exuded from roots of encroaching plants influence the growth of microorganisms around the rhizosphere, which themselves alter the soil environment $[59,60]$. Encroaching plants can effectively replace native plants by establishing plant-soil feedbacks beneficial to encroaching plants [61,62]. Li et al. (2016) have suggested that D. angustifolia changes the soils' nutrient and microbial structure to form an environment suitable for its own growth [63] and establishment. Therefore, D. angustifolia may take advantage of its ability in nutrient absorption and alteration on plant-soil feedback through belowground competition. 


\subsection{Implications for Vegetation Carbon Stock in Alpine Tundra}

Tundra vegetation dominated by native shrubs sequesters a significant amount of atmospheric carbon [64]. Previous studies have shown that climate warming causes changes of carbon stocks in the vegetation of alpine tundra $[11,65-68]$. A previous study of this system found that there were no significant changes in vegetative structure [29], indicating that climate warming would have limited impacts on the carbon stocks in the alpine tundra of Changbai Mountains. However, results of this study showed that $D$. angustifolia encroachment led to decreases in vegetative carbon stocks. Hence, the indirect effects of climate change on plant community structure, via plant encroachment, may play an important role in changing vegetation carbon storage in this alpine tundra ecosystem. With the herbaceous species continuing to expand and replace native plant species, the alpine tundra of the Changbai Mountains may become a carbon source.

\section{Conclusions}

Our study revealed that herbaceous encroachment in alpine tundra altered biomass allocation of native plant communities through above- and belowground competition. With the increasing level of encroachment, growth of native $R$. aureum was suppressed by encroaching D. angustifolia. Hence, competition played an important role in controlling community dynamics. We found that biomass allocation changed with the increasing levels of encroachment at species ( $R$. aureum and D. angustifolia) and community scales. D. angustifolia increased both above- and belowground biomass while aboveand belowground biomass of $R$. aureum decreased with the increasing level of encroachment. Thus, D. angustifolia gained advantages through both above- and belowground competition. To compete with $D$. angustifolia, $R$. aureum exhibited phenotypic plasticity in two morphological features (increased height and leaf area) to ensure adequate photosynthesis. D. angustifolia encroachment reduced the total biomass of communities. Our research highlights the fact that continued expansion by D. angustifolia should decrease the vegetative carbon stock of alpine tundra in the future.

Supplementary Materials: The following are available online at http:/ / www.mdpi.com/1999-4907/10/2/170/ s1. Table S1: Tests of between-subjects' effects of $R$. aureum biomass, height and leaf area; Table S2: Tests of between-subjects' effects of $D$. angustifolia biomass, height and leaf area.

Author Contributions: X.T. designed the experimental protocol, conceived the experiment, developed and designed the methodology, collected and preprocessed the data, analyzed and synthesized study data, analyzed the results, and wrote the initial draft. H.S.H. conceived the experiment, advised on the experimental protocol, developed and designed the methodology, advised on data analysis, provided critical review, commentary, and revision, and supplied the project with financial support leading to this publication. S.Z. conceived the experiment and advised on the experimental protocol, developed and designed the methodology, advised on data analysis, provided critical review, commentary, and revision, and supplied the project financial support leading to this publication. M.W. developed and designed the methodology, and collected and preprocessed the data. K.L. developed and designed the methodology. D.Z. developed and designed the methodology.

Funding: This research was funded by the National Key Research and Development Program of China (No. 2017YFA0604403 and 2016YFA0602301), the National Natural Science Foundation of China (No. 41501089 and 41471085), and the Natural Science Foundation of Jilin Scientific Institute (No. 20180520087JH).

Acknowledgments: We thank Sarah Humfeld for proofreading the English to improve the manuscript. We thank Risu Na and Jianan He for participating in field sampling and Hudong Han and Yongcai Dang for sample pretreatment.

Conflicts of Interest: The authors declare no conflict of interest.

\section{References}

1. Körner, C.; Paulsen, J. A world-wide study of high altitude treeline temperatures. J. Biogeogr. 2004, 31, 713-732. [CrossRef]

2. Alexander, J.M.; Lembrechts, J.J.; Cavieres, L.A.; Daehler, C.; Haider, S.; Kueffer, C.; Liu, G.; McDougall, K.; Milbau, A.; Pauchard, A.; et al. Plant invasions into mountains and alpine ecosystems: current status and future challenges. Alp. Botany 2016, 126, 89-103. [CrossRef] 
3. Barros, A.; Pickering, C.M. Non-native Plant Invasion in Relation to Tourism Use of Aconcagua Park, Argentina, the Highest Protected Area in the Southern Hemisphere. Mt. Res. Dev. 2014, 34, 13-26. [CrossRef]

4. Fernández-Murillo, M.P.; Rico, A.; Kindlmann, P.; Fernández-Murillo, M.P. Exotic plants along roads near La Paz, Bolivia. Weed Res. 2015, 55, 565-573. [CrossRef]

5. Seipel, T.; Kueffer, C.; Naylor, B.J.; Jakobs, G.; McDougall, K.; Walsh, N.; Rew, L.J.; Daehler, C.C.; Pauchard, A.; Alexander, J.M.; et al. Processes at multiple scales affect richness and similarity of non-native plant species in mountains around the world. Global Ecol. Biogeogr. 2011, 21, 236-246. [CrossRef]

6. Kalwij, J.M.; Robertson, M.P.; Van Rensburg, B.J. Annual monitoring reveals rapid upward movement of exotic plants in a montane ecosystem. Biol. Invasions 2015, 17, 3517-3529. [CrossRef]

7. Pauli, H.; Gottfried, M.; Reiter, K.; Klettner, C.; Grabherr, G. Signals of range expansions and contractions of vascular plants in the high Alps: observations (1994-2004) at the GLORIA master site Schrankogel, Tyrol, Austria. Glob. Change Biol. 2007, 13, 147-156. [CrossRef]

8. Walther, G.-R.; Beißner, S.; Burga, C.A. Trends in the upward shift of alpine plants. J. Veg. Sci. 2005, 16, 541-548. [CrossRef]

9. Elmendorf, S.C.; Henry, G.H.R.; Hollister, R.D.; Björk, R.G.; Boulanger-Lapointe, N.; Cooper, E.J.; Cornelissen, J.H.C.; Day, T.A.; Dorrepaal, E.; Elumeeva, T.G.; et al. Plot-scale evidence of tundra vegetation change and links to recent summer warming. Nature Clim. Change 2012, 2, 453-457. [CrossRef]

10. Hudson, J.M.G.; Henry, G.H.R.; Cornwell, W.K. Taller and larger: shifts in Arctic tundra leaf traits after 16 years of experimental warming. Glob. Change Biol. 2011, 17, 1013-1021. [CrossRef]

11. Nie, Y.-Q.; Kong, G.-Q.; Liu, X.-S.; Luo, T.-X. Contrasting changes in above- and below-ground biomass allocation across treeline ecotones in southeast Tibet. J. Mt. Sci. 2016, 13, 2036-2045.

12. Muñoz, A.A.; Cavieres, L.A. The presence of a showy invasive plant disrupts pollinator service and reproductive output in native alpine species only at high densities. J. Ecol. 2008, 96, 459-467. [CrossRef]

13. Grime, J.P. Evidence for the Existence of Three Primary Strategies in Plants and Its Relevance to Ecological and Evolutionary Theory. Am. Nat. 1977, 111, 1169-1194. [CrossRef]

14. Godoy, O.; Levine, J.M. Phenology effects on invasion success: insights from coupling field experiments to coexistence theory. Ecology 2014, 95, 726-736. [CrossRef]

15. Hermans, C.; Hammond, J.P.; White, P.J.; Verbruggen, N. How do plants respond to nutrient shortage by biomass allocation? Trends Plant Sci. 2006, 11, 610-617. [CrossRef] [PubMed]

16. Wang, P.; Wang, T.; Zhou, D.; Zhang, H. A literature review on the above- and below-ground competition. Acta Eco. Sinica 2007, 27, 3489-3499.

17. Bloom, A.J.; Chapin, F.S.; A Mooney, H. Resource Limitation in Plants-An Economic Analogy. Annu. Rev. Ecol. Syst. 1985, 16, 363-392. [CrossRef]

18. Gargaglione, V.; Peri, P.L.; Rubio, G. Allometric relations for biomass partitioning of Nothofagus antarctica trees of different crown classes over a site quality gradient. For. Ecol. Manag. 2010, 259, 1118-1126. [CrossRef]

19. Seabloom, E.W.; Harpole, W.S.; Reichman, O.J.; Tilman, D. Invasion, competitive dominance, and resource use by exotic and native California grassland species. Proc. Natl. Acad. Sci. 2003, 100, 13384-13389. [CrossRef] [PubMed]

20. Dormann, C.; Woodin, S.J. Climate change in the Arctic: using plant functional types in a meta-analysis of field experiments. Funct. Ecol. 2002, 16, 4-17. [CrossRef]

21. Henry, G.; Freedman, B.; Svoboda, J. Survey of Vegetated Areas and Muskox Populations in East-Central Ellesmere Island. ARCTIC 1986, 39, 78-81. [CrossRef]

22. Rejmánek, M.; Richardson, D.M. What Attributes Make Some Plant Species More Invasive? Ecology 1996, 77, 1655-1661.

23. Rudak, A.; Wódkiewicz, M.; Znój, A.; Chwedorzewska, K.J.; Galera, H. Plastic biomass allocation as a trait increasing the invasiveness of annual bluegrass (Poa annua L.) in Antarctica. Polar Biol. 2018, 42, 149-157. [CrossRef]

24. Zong, S.; Xu, J.; Wu, Z. Investigation and mechanism analysis on the invasion of deyeuxia. Angustifolia to tundra zone in western slope of changbai mountain. J, Mt. Sci. 2013, 31, 448-455.

25. Williamson, M.H.; Fitter, A. The characters of successful invaders. Biol. Conserv. 1996, 78, 163-170. [CrossRef]

26. Qian, J.J.; Zhang, W.Z. Vertical Plant List of the Changbai Mountains; Northeast Normal University Press: Changchun, China, 1979; pp. 90-95.

27. Qian, H. Alpine tundra vegetation on the Changbai Mountains. For. Res. Eco. 1992, 6, 72-93. 
28. Zong, S. Mechanism research on the vegetation changes of the sub-alpine tundra, Changbai Mountains. Ph.D. Thesis, Northeast normal university, Changchun, China, 2014.

29. Zong, S.; Jin, Y.; Xu, J.; Wu, Z.; He, H.; Du, H.; Wang, L. Nitrogen deposition but not climate warming promotes Deyeuxia angustifolia encroachment in alpine tundra of the Changbai Mountains, Northeast China. Sci. Total Environ. 2016, 544, 85-93. [CrossRef] [PubMed]

30. Zong, S.; Wu, Z.; Du, H. Study on climate change in alpine tundra of the changbai mountain in growing season in recent 52 years. Arid Zone Res. 2013, 30, 41-49.

31. Wang, L. Research on the spatial distribution pattern of plant communities in tundra in the west slope of changbai mountain besed on water and heat balance. Ph.D. Thesis, Northeast normal university, Changchun, China, 2017.

32. Wu, M.; He, H.S.; Zong, S.; Tan, X.; Du, H.; Zhao, D.; Liu, K.; Liang, Y. Topographic Controls on Vegetation Changes in Alpine Tundra of the Changbai Mountains. Forests 2018, 9, 756. [CrossRef]

33. Dunne, J.A.; Saleska, S.R.; Fischer, M.L.; Harte, J. INTEGRATING EXPERIMENTAL AND GRADIENT METHODS IN ECOLOGICAL CLIMATE CHANGE RESEARCH. Ecology 2004, 85, 904-916. [CrossRef]

34. Ma, W.; Shi, P.; Li, W.; He, Y.; Zhang, X.; Shen, Z.; Chai, S. Changes in individual plant traits and biomass allocation in alpine meadow with elevation variation on the Qinghai-Tibetan Plateau. Sci. China Life Sci. 2010, 53, 1142-1151. [CrossRef] [PubMed]

35. Liu, M.; Liu, G.; Kang, Y.; Zhang, S.; Wu, Y.; Wang, Y. Responses of leaf morphological and anatomical structure to elevation in an alpine plant meconopsis integrifolia. Chin. J. Ecol. 2018, 37, 35-42.

36. Wang, P.; Mommer, L.; Van Ruijven, J.; Berendse, F.; Maximov, T.C.; Heijmans, M.M.P.D. Seasonal changes and vertical distribution of root standing biomass of graminoids and shrubs at a Siberian tundra site. Plant Soil 2016, 407, 55-65. [CrossRef]

37. Niu, K.; Luo, Y.; Choler, P.; Du, G. The role of biomass allocation strategy in diversity loss due to fertilization. Basic Appl. Ecol. 2008, 9, 485-493. [CrossRef]

38. Wu, J.-S.; Shen, Z.-X.; Zhang, X.-Z.; Shi, P.-L. Biomass allocation patterns of alpine grassland species and functional groups along a precipitation gradient on the Northern Tibetan Plateau. J. Mt. Sci. 2013, 10, 1097-1108. [CrossRef]

39. Heer, C.; Körner, C. High elevation pioneer plants are sensitive to mineral nutrient addition. Basic Appl. Ecol. 2002, 3, 39-47. [CrossRef]

40. Connell, J.H. On the Prevalence and Relative Importance of Interspecific Competition: Evidence from Field Experiments. Am. Nat. 1983, 122, 661-696. [CrossRef]

41. Callaway, R.M.; Brooker, R.W.; Choler, P.; Kikvidze, Z.; Lortie, C.J.; Michalet, R.; Paolini, L.; Pugnaire, F.I.; Newingham, B.; Aschehoug, E.T.; et al. Positive interactions among alpine plants increase with stress. Nature 2002, 417, 844-848. [CrossRef] [PubMed]

42. Liu, Q.; Xu, Q.; Zhang, G. Impact of alpine snowpacks on primary productivity in rhododendron aureum community in changbai mountain, China. Acta Ecol. Sinica 2009, 29, 4035-4044.

43. McDougall, K.L.; Morgan, J.W.; Walsh, N.G.; Williams, R.J. Plant invasions in treeless vegetation of the Australian Alps. Perspect. Plant Ecol. Evol. Syst. 2005, 7, 159-171. [CrossRef]

44. Gaur, U.N.; Raturi, G.; Bhatt, A. Quantitative Response of Vegetation in Glacial Moraine of Central Himalaya. Environmentalist 2003, 23, 237-247. [CrossRef]

45. Beckage, B.; Osborne, B.; Gavin, D.; Pucko, C.; Siccama, T.; Perkins, T. A rapid upward shift of a forest ecotone during 40 years of warming in the Green Mountains of Vermont. Proc. Natl. Acad. Sci. 2008, 105, 4197-4202. [CrossRef] [PubMed]

46. Wei, P.; Zhang, R.; Wang, P.; Yuan, Z.; Du, J. Species interactions occurring in the alpine meadow from the eastern Qinghai-Tibet plateau of China. J. Lanzhou Univ. (Nat. Sci.) 2011, 47, 79-89.

47. Saccone, P.; Hoikka, K.; Virtanen, R. What if plant functional types conceal species-specific responses to environment? Study on arctic shrub communities. Ecology 2017, 98, 1600-1612. [CrossRef] [PubMed]

48. Wheeler, J.A.; Hoch, G.; Cortés, A.J.; Sedlacek, J.; Wipf, S.; Rixen, C. Increased spring freezing vulnerability for alpine shrubs under early snowmelt. Oecologia 2014, 175, 219-229. [CrossRef]

49. Vo, S.T.K.; Johnson, E.A. Alpine Plant Life: Functional Plant Ecology of High Mountain Ecosystems. Mt. Res. Dev. 2001, 21. [CrossRef]

50. Larcher, W.; Siegwolf, R. Development of acute frost drought in Rhododendron ferrugineum at the alpine timberline. Oecologia 1985, 67, 298-300. [CrossRef] 
51. Iversen, C.M.; Sloan, V.L.; Sullivan, P.F.; Euskirchen, E.S.; McGuire, A.D.; Norby, R.J.; Walker, A.P.; Warren, J.M.; Wullschleger, S.D. The unseen iceberg: plant roots in arctic tundra. New Phytol. 2014, 205, 34-58. [CrossRef]

52. Björk, R.G.; Majdi, H.; Klemedtsson, L.; Molau, U.; Lewis-Jonsson, L.; Lewis-Jonsson, L. Long-term warming effects on root morphology, root mass distribution, and microbial activity in two dry tundra plant communities in northern Sweden. New Phytol. 2007, 176, 862-873. [CrossRef]

53. Zhu, J.; Jiang, L.; Zhang, Y.; Jiang, Y.; Tao, J.; Tian, L.; Zhang, T.; Xi, Y. Below-ground competition drives the self-thinning process of Stipa purpurea populations in northern Tibet. J. Veg. Sci. 2014, 26, 166-174. [CrossRef]

54. Van Ruijven, J.; Schaepman-Strub, G.; Wang, P.; Limpens, J.; Mommer, L.; Nauta, A.L.; Berendse, F.; Blok, D.; Maximov, T.C.; Heijmans, M.M.; et al. Above- and below-ground responses of four tundra plant functional types to deep soil heating and surface soil fertilization. J. Ecol. 2017, 105, 947-957.

55. Mallen-Cooper, J. Introduced plants in the high-altitude environments of Kosciusko National Park, South-Eastern Australia. Ph.D. Thesis, Australian National University, Canberra, Australian, 1990.

56. Li, L. Study on Soil Microorganism of subalpine tundra in Changbai Mountain. Ph.D. Thesis, Jilin University, Changchun, China, 2017.

57. Wearne, L.J.; Morgan, J.W. Shrub invasion into subalpine vegetation: implications for restoration of the native ecosystem. Plant Ecol. 2006, 183, 361-376. [CrossRef]

58. Funk, J.L.; Vitousek, P.M. Resource-use efficiency and plant invasion in low-resource systems. Nature 2007, 446, 1079-1081. [CrossRef] [PubMed]

59. Hendriks, M.; Ravenek, J.M.; Smit-Tiekstra, A.E.; Van Der Paauw, J.W.; De Caluwe, H.; Van Der Putten, W.H.; De Kroon, H.; Mommer, L.; Smit-Tiekstra, A.E. Spatial heterogeneity of plant-soil feedback affects root interactions and interspecific competition. New Phytol. 2015, 207, 830-840. [CrossRef] [PubMed]

60. Ehrenfeld, J.G.; Ravit, B.; Elgersma, K. Feedback in the plant-soil system. Annu. Rev. Environ. Resour. 2005, 30, 75-115. [CrossRef]

61. Yu, X. A new mechanism of invader success: Exotic plant inhibits natural vegetation restoration by changing soil microbe com-munity. Chin. Sci. Bull. 2005, 50. [CrossRef]

62. Li, W.-H.; Zhang, C.-B.; Jiang, H.-B.; Xin, G.-R.; Yang, Z.-Y. Changes in Soil Microbial Community Associated with Invasion of the Exotic Weed, Mikania micrantha H.B.K. Plant Soil 2006, 281, 309-324. [CrossRef]

63. Li, L.; Xing, M.; Lv, J.; Wang, X.; Chen, X. Response of rhizosphere soil microbial to Deyeuxia angustifolia encroaching in two different vegetation communities in alpine tundra. Sci. Rep. 2017, 7. [CrossRef]

64. Oechel, W.C.; Hastings, S.J.; Vourlrtis, G.; Jenkins, M.; Riechers, G.; Grulke, N. Recent change of Arctic tundra ecosystems from a net carbon dioxide sink to a source. Nature 1993, 361, 520-523. [CrossRef]

65. Speed, J.D.M.; Martinsen, V.; Hester, A.J.; Holand, Ø.; Mulder, J.; Mysterud, A.; Austrheim, G. Continuous and discontinuous variation in ecosystem carbon stocks with elevation across a treeline ecotone. Biogeosciences 2015, 12, 1615-1627. [CrossRef]

66. Sjögersten, S.; Wookey, P.A. The Impact of Climate Change on Ecosystem Carbon Dynamics at the Scandinavian Mountain Birch Forest-Tundra Heath Ecotone. AMBIO 2009, 38, 2-10.

67. Körner, C. Treelines Will be Understood Once the Functional Difference Between a Tree and a Shrub Is. AMBIO 2012, 41, 197-206. [CrossRef] [PubMed]

68. Grafius, D.R.; Malanson, G.P. Biomass distributions in dwarf tree, krummholz, and tundra vegetation in the alpine treeline ecotone. Phys. Geogr. 2015, 36, 337-352. [CrossRef]

(C) 2019 by the authors. Licensee MDPI, Basel, Switzerland. This article is an open access article distributed under the terms and conditions of the Creative Commons Attribution (CC BY) license (http://creativecommons.org/licenses/by/4.0/). 